\title{
NILAI-NILAI PENDIDIKAN ISLAM DALAM MEMBENTUK BUDAYA RELIGIUS DI SMA NEGERI 1 GENTENG TAHUN PELAJARAN 2017/2018
}

\author{
Ahmad Aziz Fanani ${ }^{1}$ \\ fananiahmadaziz89@gmail.com \\ ${ }^{1}$ Fak. Tarbiyah, IAI Ibrahimy Genteng Banyuwangi, Indonesia \\ Imam Mashuri ${ }^{2}$ \\ mashuri5758.aba@gmail.com \\ ${ }^{2}$ Fak. Tarbiyah, IAI Ibrahimy Genteng Banyuwangi, Indonesia \\ Dina Istiningrum ${ }^{3}$ \\ dinaisti17@gmail.com \\ ${ }^{3}$ Fak. Tarbiyah, IAI Ibrahimy Genteng Banyuwangi, Indonesia
}

\begin{abstract}
Today the need of education is increasingly high, but it is inversely proportional to the condition of education that is increasingly regressive. This happened because of the development of science, knowledge, and technology (modernism) which had a negative impact on moral decadence. Because of this threat, Islamic education as a branch of aespecially scientific discipline is expected to be a solution to the threat. Therefore, educational institutions must be able to be pioneers in improving the character of students, namely by implementing policies or programs that lead to Islamic education. One of them has been done by a nonIslamic national standard school, namely SMA Negeri 1 Genteng, which has instilled Islamic values in the educational environment.
\end{abstract}

Keyword: Islamic Education Values, Religious Culture 


\section{Pendahuluan}

Tingginya kebutuhan akan pentingnya pendidikan berbanding terbalik dengan perkembangan dunia pendidikan dewasa ini. Dunia pendidikan selama kurun waktu beberapa tahun terakhir ini mengalami regresif, hal ini sebanding dengan tantangan pendidikan yang harus dilalui oleh masing-masing lembaga pendidikan sebagai dampak dari arus perkembangan ilmu, pengetahuan dan teknologi (postmodernisme). Tantangan ini berupa dampak negatif yang harus dihadapi, utamanya mengenai ancaman dekadensi moral. Modernisasi memberikan suatu perubahan yang signifikan dalam tatanan kehidupan manusia, pada suatu sisi manusia dijembatani pada era berkemajuan, namun di sisi lain modernisasi memunculkan konflik-konflik sosial. (Nasri Kurnialloh, 2012).

Menyikapi bahaya modernisasi, peran pendidikan agama menempati posisi yang sangat penting dalam memecahkan masalah atau konflik sosial di masyarakat utamanya mengenai dekadensi moral. Hal ini sebagaimana Peraturan Pemerintah Nomor 55 Tahun 2007 Tentang Pendidikan Agama dan Pendidikan Keagamaan Pasal 5 ayat 3 bahwa "Pendidikan Agama mendorong peserta didik untuk taat menjalankan ajaran agamanya dalam kehidupan sehari-hari dan menjadikan agama sebagai landasan etika dan moral dalam kehidupan pribadi, berkeluarga, bermasyarakat, berbangsa dan bernegara". Ada beberapa indikator yang menjadikan kurang berhasilnya pendidikan agama di sekolah khususnya dan di masyarakat umumnya, yakni masih terdapat pemisah atau sekat antara pemahaman agama masyarakat dengan perilaku religius yang diharapkan, seperti tawuran, penggunaan narkoba, pencurian, pemerkosaan, pergaulan bebas, dan sebagaimana. (Asmaun Sahlan, Muhibuddin Hanifah, 2010). Salah satu contoh kasus kekerasan yang 
dilakukan murid pada gurunya, berita ini di lansir dari berita harian www.kompas.com edisi Jumat 02 Pebruari 2018, diterangkan bahwa seorang peserta didik salah satu SMA Negeri di Torjun, Sampang-Madura telah menganiaya seorang guru hingga mengakibatkan guru tersebut meninggal dunia. Adanya kenyataan dan indikator-indikator tersebut bisa dijadikan bahan kajian bagi para pakar dan praktisi pendidikan untuk mulai mengupayakan pembenahan dan perbaikan terhadap sistem pendidikan yang semakin bobrok, melalui program-program yang dapat mewujudkan nilai-nilai keagamaan pada peserta didik secara serius dan berkelanjutan. (Asmaun Sahlan, D. Brighthouse. J, Woodsbahwa 2010). Oleh karena itu, lembaga pendidikan seyogyanya menjadi pionir dalam pembenahan karakter karena pasti lebih dulu mengetahui tentang dekadensi moral dan bahaya modernisme di depan mata generasi penerus. (Asmani, 2013). Hal lain yang bisa dijadikan beberapa penguatan yang dapat dilakukan oleh lembaga pendidikan, yaitu: penguatan melalui proses, pembelajaran, ekstrakurikuler, dan pembudayaan nilai-nilai religius di sekolah. (Usman, Zamzami, 2015). Oleh karena itu penanaman nilai-nilai moral dan norma-norma sosial secara tidak langsung melalui pendidikan agama khususnya agama Islam perlu diterapkan dalam pendidikan di Indonesia secara terus menerus, demi tercapainya pendidikan yang diharapkan.

Macam-macam nilai pendidikan Islam yang harus diajarkan secara intens untuk membentuk budaya religius, menurut Kurnialoh tahun 2015 berdasarkan sumber al Qur'an dan al Hadist meliputi tiga dimensi, yaitu: 1) dimensi spiritual, dimensi yang berhubungan dengan keyakinan, ketaqwaan dan akhlak seseorang yang tercerminkan dari pelaksanaan ibadah dan muamalah; 2) dimensi budaya, dimensi yang berhubungan dengan kepribadian seorang muslim yang mandiri dan bertanggung 
jawab kepada masyarakat dan bangsa, dimana kepribadian ini merupakan hasil perkembangan yang dipengaruhi oleh bawan dan dasar dan lingkungan; 3) dimensi kecerdasan, dimensi yang berhubungan dengan kemajuan individu untuk potensi-potensi yang baik, seperti kreatif, terampil, cerdas, disiplin, produktif, profesional, etos kerja dan inovatif. Sedangkan nilai-nilai yang menjadi ruh pendidikan Islam meliputi: nilai ubudiyah, nila moralitas/akhlakul karimah, nilai kedisiplinan. Nilai-nilai yang ada dalam pendidikan Islam perlu adanya usaha atau cara untuk membentuk penanaman nilai-nilai tersebut (Zulkarnain, 2008). Oleh karena itu beberapa bentuk penanaman nilainilai pendidikan Islam, yaitu: 1) keteladanan, memberikan gambaran kepada peserta didik untuk melakukan seperti apa yang dilihatnya; 2) pembiasaan, pembiasaan sangat efektif karena akan melatih kebiasaan anak jika dilakukan sejak dini; 3) nasihat, merupakan bentuk penanaman yang fleksibel yang dapat dilaksanakan di kapanpun dan di manapu ketika pendidik melihat suatu pelanggaran yang dilakukan oleh peserta didik; 4) hukuman/punishment, penanaman nilai dalam bentuk ini dalam satuan pendidikan bertujuan untuk mengiringi proses pembelajaran agar tercapai tujuan yang diharapkan (Ansori, dkk. 2017). Penanaman nilainilai pendidikan Islam dengan baik dan benar akan menghasilkan budaya religius di lingkungan sekolah. Budaya-budaya religius di sekolah yaitu: senyum sapa dan salam, saling hormat dan toleran, shalat Dhuha, Istighosah dan doa bersama, tadarrus al Qur'an (Asmaun Sahlan, 2010). Senyum sapa dan salam dalam perspektif budaya menunjukkan bahwa komunitas masyarakat sekolah memiliki kedamian, santun, saling tenggang rasa, toleran dan rasa hormat. Saling hormat dan toleran, sikap ini sejalan dengan konsep ukhuwah dan tawadlu' dalam ajaran Islam. Shalat Dhuha, shalat merupakan bentuk peribadatan yang diwajibkan oleh setiap umat muslim. Kaitannya dengan pendidikan kemudian 
menjadi budaya religius di sekolah merupakan nilai tambah bagi peserta didik. Dalam Islam seorang yang akan menuntut ilmu dianjurkan untuk melakukan pensucian diri baik secara fisik dan rohani. Istighosah dan doa bersama sebenarnya adalah untuk taqqarub atau mendekatkan diri kepada Allah dengan tujuan meminta pertolongan kepada Allah. Tadarus al Qur'an merupakan bentuk peribadatan yang juga tujuanya adalah untuk mendekatkan diri pada Allah SWT. Taddarus al-Quran memberikan implikasi pada peserta didik seperti; sikap berperilaku positif, tenang, lisan terjaga dan istiqamah yang nantinya akan berpengaruh terhadap hasil prestasi peserta didik.

Berdasarkan pengamatan yang dilakukan oleh peneliti di tengah arus kemajuan ilmu, pengetahuan, teknologi dan informasi, serta kegundahan orang tua pada lembaga pendidikan nonkeislaman, terdapat suatu lembaga pendidikan formal jenjang SMA berbasis nonkeislaman di bawah naungan pemerintah yang berstatus sebagai sekolah negeri yang menerapkan nilai-nilai keagamaan secara baik dan termasuk salah satu anggota sekolah Adiwiyata, sekolah tersebut adalah SMA Negeri 1 Genteng.SMA Negeri 1 Genteng merupakan sekolah yang mempunyai segudang prestasi di bidang akademik maupun non-akademik yang tidak hanya berfokus pada aspek kognitif saja, melainkan juga memiliki keistimewaan lain yang jarang ada di sekolah negeri nonkeislaman. Sekolah ini sudah melakukan suatu reformulasi di dunia pendidikan yang tidak mendikotomikan keilmuan, baik keilmuan yang bersifat sains umum dan sains keislaman. Sebagaimana yang disampaikan Zulkarnain (2008:64) bahwa penyelenggaraan pendidikan tidak hanya menjalankan proses pemindahan ilmu (transfer of knowledge) melainkan harus terdapat proses penanaman nilai-nilai (transfer of values) pada setiap aktivitas pembelajaran, utamanya nilai-nilai religius. 


\section{Metode Penelitian}

Penelitian ini jenis penelitian kualitatif model diskriptif, dengan pengambilan sample menggunakan teknik purposive sampling. Sebagai tempat penelitian di SMAN 1 Genteng Banyuwangi dengan alamat Jalan KH. Wahid Hasyim No 20 Genteng.

Subyek penelitian yaitu siswa kelas X dan XI, Kepala Sekolah, dan Guru Pendidikan Agama Islam. Obyek penelitian yang dikaji adalah nilaai-nilai pendidikan Islam yang meliputi nilai ubudiyah, nilai moralitas, nilai kedisiplinam, serta wujud budaya religius di SMAN 1 Genteng.

Keabsahan data yang digunakan uji kredibilitas dan triangulasi. Metode pengumpulan data yang digunakan adalah observasi, wawancara, dan dokumnetasi. Observasi yang dipilih observasi pertisipasif moderat yaitu peneliti melakukan dan merasakan suka duka yang dilakukan oleh sumber data. Wawancara yang dipilih wawancara semi terstruktur agar diperoleh data lebih terbuka dengan meminta pendapat atau ide dari sumber data. Dokumentasi yang digali meliputi foto kegiatan yang berkaitan dengan obyek penelitian dan data data yang mendukung penelitian.

Teknik analisis data menggunakan teori Miles dan Huberman, yaitu reduksi data (rangkuman), data display (penyajian), dan kesimpulan. Data yang disimpulkan bersifat sementara, maksudnya data yang disajikan sesuai dengan data lapangan. 


\section{Pembahasan}

\section{Nilai-nilai Pendidikan Islam yang Tertanam di SMA Negeri 1 Genteng untuk Membentuk Budaya Religius}

SMA Negeri 1 Genteng merupakan salah satu sekolah umum yang tidak mendikotomikan keilmuan, baik keilmuan sain umum dan sain keagamaan, hal ini terlihat dari pendidikan Islam yang begitu kental di sana, sehingga tercipta kegiatan keagamaan baik saat pembelajaran dan di luar pembelajaran menjadi budaya atau tradisi kebiasaan sehari-hari tampak begitu religius. Hal ini menunjukkan bahwa sekolah tidak hanya sebagai tempat menambah ilmu pengetahuan saja, namun juga sebagai tempat untuk menjadikan peserta yang berkarakter.

Sebagaimana dari pengamatan peneliti yang menunjukkan adanya kebiasaan-kebiasaan religius menunjukkan adanya nilai-nilai pendidikan Islam yang sudah tertanam di SMA Negeri 1 Genteng sangat baik.Sebagaimana pendapat Zulkarnain pada tahun 2008 bahwa tiga nilai ini yang menjadi ruh pendidikan Islam di sekolah. Di antara nilai-nilai pendidikan Islam yang tertanam di SMA Negeri 1 Genteng yaitu:

\section{a. Nilai Ubudiyah}

SMA Negeri 1 Genteng sebagai lembaga pendidikan umum dalam melaksanakan peribadatan begitu baik.Sekolah dengan peserta didik yang berlatar belakang agama yang berbeda ini begitu menjaga dan 
menghargai orang dalam beribadah. Hal ini tidak lepas dari upaya warga sekolah utamanya guru PAI dalam menanamkan nilai ubudiyahyaitu saat jam pembelajaran maupun di luar pembelajaran, salah satu contohnya adalah ditanamkan adalah dalam penyampaiaan materi di kelas dan langsung dalam kehidupan sehari-hari seperti adanya kesadaran dan kewajiban melaksanakan ibadah, baik ibadah yang bersifat mahdhah dan ghairu mahdhah oleh warga sekolah. Adanya bekal ilmu pengetahuan serta didukung dengan adanya kesadaran dan kewajiban dalam menanamkan nilai ubudiyahakan mempermudah bagi para guru ataupun peserta didik dalam menciptakan suasana religius yang kemudian menjadi sebuah tradisi yang membudaya di sekolah.

\section{b. Nilai Moralitas}

Nilai moralitas yang terdapat di SMA Negeri 1 Genteng begitu kental, selain latar belakang agama yang berbeda, status sosial yang ada di sekolah juga bersifat heterogen, sehingga peserta didik akan dihadapkan pada kondisi lingkungan yang beragam. Hal ini akan melatih peserta didik bersikap dan bertindak menghadapi persoalan yang muncul baik dalam pembelajaran, di luar pembelajaran maupun berorganisasi. Oleh karena itu penanaman nilai moralitas dapat dilihat dari kesantunan, kedermawanan dan kegotong royongan peserta didik.

\section{1) Santun}

Sikap kesantunan peserta didik menunjukkan seberapa besar rasa saling hormat terhadap orang lain, tanpa memandang latar belakang baik agama, sosial dan usia. Sikap santun dapat menjadikan suasana di dalam lingkungan pendidikan lebih religius yang sudah menjadi tradisi di SMA Negeri 1 Genteng, di antaranya terlaksana penanaman 5 S (senyum, sapa, 
salam, sopan dan santun). Setiap pagi di depan gerbang sekolah sebelum pembelajaran di mulai, ada beberapa guru yang berdiri di depan gerbang untuk menyambut peserta didik dengan menyapa, bersalaman dan tersenyum. Hal ini dilakukan sebagai bentuk keteladanan guru dan pembiasaan bagi peserta didik untuk berlaku santun terhadap yang lebih tua dan saling menghormati sesama.

\section{2) Kedermawanan}

Sikap kedermawanana adalah salah satu sikap yang muncul karena adanya sikap peduli terhadap sesama yang membutuhkan bantuan, baik dalam bentuk moril dan materil.Timbulnya rasa peduli ini memunculkan sikap kedermawanan tanpa memandang latar belakang/background. Peserta didik mengadakan suatu program yang mereka sebut dengan istilah "Jumat Peduli", kegiatan solidaritas yang diadakan setiap satu minggu sekali di hari Jumat. Kegiatan ini bertujuan dalam memecahkan masalah yang sedang dihadapi bersama oleh peserta didik utamanya dalam membantu teman yang mengalami musibah atau kesulitan dana dan lain sebagainya.Kegaiatan yang dimunculkan oleh peserta didik karena timbulnya rasa kepedulian yang tinggi terhadap sesama ini melatih moralitas mereka untuk peduli terhadap sesama.

\section{3) Kegotong royongan}

Sikap kegotong royongan akan menunjukkan seberapa besar sikap moral yang dimiliki oleh peserta didik melihat latar belakang dari SMA Negeri 1 Genteng yang bersifat heterogen. Sikap toleransi yang timbul dari peserta didik lintas agama menimbulkan rasa gotong royong setiap pada kegiatan sekolah, walaupun kegiatan itu bukan kegiatan keagamaan saja, hal ini dilandasi sikap profesionalitas yang tinggi dalam berorganisasi oleh para 
anggotanya.Adanya toleransi, sikap saling menghargai dan profesionalisme dalam berorganisasi menimbulkan sikap kepedulian berupa gotong-royong atau saling membantu baik kegiatan keagamaan atau pun non keagamaan, hal ini menunjukkan bahwa nilai moralitas tertanam dengan baik di SMA Negeri 1 Genteng.

\section{c. Nilai Kedisiplinan}

Nilai kedisiplinan dari peserta didik SMA Negeri 1 Genteng sangat baik.Sebagaimana misi SMA Negeri 1 Genteng adalah "menanamkan kedisiplinan melalui budaya bersih, budaya tertib, dan budaya kerja serta mencegah kerusakan lingkungan".kedisiplinan yang tertanam di SMA Negeri 1 Genteng adalah adanya kesadaran dari warga sekolah terhadap kesepakan bersama yang sudah dibuat bersama. Hal ini menunjukkan adanya rasa tanggung jawab, komitmen yang kuat dan etos kerja yang tinggi dalam menjaga kedisiplinan tersebut.Oleh karena ini, hal ini bisa menjadi tolok ukur dari penanaman nilai kedesiplinan di SMA Negeri 1 Genteng sudah tertanam.

\section{1) Komitmen Kuat}

Komitmen kuat yang terdapat di SMA Negeri 1 Genteng ditandai dari kedisiplinan berpakaian.SMA Negeri 1 Genteng sebagai sekolah umum yang bukan lembaga keislaman, namun mempunyai pemandangan yang religius. Budaya berpakaian bagi yang Muslim khususnya Wanita (muslimah) mereka mengenakan pakaian yang menutup aurat, hal ini menunjukkan bahwa mereka mempunyai komitmen sebagai muslimah yang baik yaitu melaksanakan kewajiban untuk menutup aurat sebagaimana perintah dalam syariat Islam khususnya, walaupun pihak sekolah tidak mewajibkan untuk berpakaian dengan memakai kerudung. 


\section{2) Bertanggung Jawab}

Rasa tanggung jawab dimunculkan oleh warga sekolah, baik guru dan peserta didik yang menjalankan kewajibannya saat pembelajaran utamanya guru melaksanakan tugas mereka saat pembelajaran di kelas dengan menyampakain ilmu. Namun ada keadaan dimana guru tidak hadir di dalam kelas karena ada rapat, para peserta didik yang berada di jam kosong tetap berada di dalam kelas dan membentuk sebuah diskusi bersama yang di tutori oleh beberapa peserta didik, sehingga suasana belajar tetap kondusif dan ada beberapa anak keluar kelas untuk melaksanakan Sholat Dhuha di masjid.

\section{3) Etos Kerja Tinggi}

Adanya etos kerja tinggi yang dilakukan oleh peserta didik menunjukkan bahwa segala sesuatu itu dilakukan dengan berusaha dan berdoa. Semangat ini dilandasi dengan tujuan dari SMA Negeri 1 Genteng dalam misinya adalah "menanamkan kedisiplinan melalui budaya bersih, budaya tertib, dan budaya kerja serta mencegah kerusakan lingkungan". berbagai prestasi dari peserta didik sangat baik, hal ini dapat dilihat dari berbagai penghargaan prestasi baik dari tingkat tingkat provinsi sampai nasional. Munculnya etos kerja tinggi ini dapat dilihat dari kesadaran peserta didik saat mengikuti lomba tanpa adanya rasa tertekan atau terpaksa, sehinnga peserta didik diberikan kesempatan untuk mengeksplor kemampuannya dengan mengikuti lomba, sehingga jika peserta didik memenuhi kriteria untuk mengikuti suatu kompetisi mereka tidak lagi sebagai penggembira saja, namun benar-benar sebagai peserta yang nantinya akan membawa nama baik sekolah. 


\section{Proses Penanaman Nilai-nilai Pendidikan Islam di SMA Negeri 1 Genteng untuk Membentuk Budaya Religius}

\section{a. Nilai Ubudiyah}

Nilai ubudiyah di SMA Negeri 1 Genteng menjadikan peserta didik mengetahui posisinya sebagai hamba Allah yang selalu senantiasa mendekatkan diri dengan berbakti atau mengabdikan dirinya pada Allah SWT. Sehingga nilai ubudiyah yang tertananam dengan baik di SMA Negeri 1 Genteng akan membentuk pribadi peserta didik yang tidak sombong dan takabur serta mengkultuskan sains dan teknologi secara sepihak, yang kemudian peserta didik secara tidak langsung mempunyai kesadaran dan kewajiban melaksanakan ibadah, baik ibadah yang bersifat mahdhah dan ghairu mahdhah.

\section{b. Nilai Moralitas}

SMA Negeri 1 Genteng mempunyai kondisi warga sekolah yang bersifat heterogen baik dari segi agama, ekonomi dan lain sebagainya. Hal ini akan menciptakan suasana yang kompleks baik saat pembelajaran dan di luar pembelajaran. Nilai moralitas yang tertanam di SMA Neregi 1 Genteng dapat dilihat dengan mengacu pada tolok ukur dengan implementasi dari adanya kesantuanan; kedermawanan dan gotong royong. Sehingga nilai moralitas yang sudah tertanam di SMA Negeri 1 Genteng akan menjadikan peserta didik yang tidak hanya memiliki kemampuan intelektual saja, namun juga mempunyaibudi pekerti yang luhur dan akhlakul karimah. 


\section{c. Nilai Kedisiplinan}

SMA Negeri 1 Genteng sebagai sekolah yang dipercaya masyarakat untuk melahirkan peserta didik yang berkualitas, tentu mempunyai motto, visi dan misi serta aturan yang berlaku.Sehingga SMA Negeri 1 Genteng mempunyai pedoman dalam melaksanakan tugasnya sebagai lembaga pendidikan beserta warga sekolahnya sebagai warga dalam lingkungan pendidikan.Nilai kedisiplinan di SMA Negeri 1 Genteng tertanam dengan baik ditandai dengan adanya komitmen yang kuat; bertanggung jawab; etos kerja yang tinggi. Oleh karena itu, bukan sesuatu yang baru lagi bagi SMA Negeri 1 Genteng jika peserta didiknya mempunyai kepribadian dan jati diri dengan sifat-sifat positif sehingga menjadi faktor pendukung dalam meraih penghargaan dan prestasi baik di tingkat nasional dan internasional.

\section{Faktor Pendukung dan Penghambat Penanaman Nilai-nilai Pendidikan Islam di SMA Negeri 1 Genteng}

Faktor pendukung dalam menanamkan nilai-nilai pendidikan Islam di SMA Negeri 1 Genteng adalah adanya kekompakan dari warga sekolah dalam menanamkan nilai-nilai pendidikan Islam serta dukungan lembaga pendidikan untuk menyediakan fasilitas sebagai penunjang penanaman nilai-nilai pendidikan Islam baik bersifat moril dan materil. Sedangkan, untuk faktor penghambat dari penanaman nilai-nilai pendidikan Islam ada beberapa hal yang menjadikan dalam penanamnya sedikit terkendala, seperti budaya bersalaman, yaitu saat dilaksanakannya penanaman nilai moralitas berupa adanya salaman di pagi hari sebagian besar yang bukan makhram lebih menjaga wudhu mereka di pagi hari. Namun hal ini dapat diatasi dengan adanya penanaman sebuah pemahaman dan pengertian bersama kaitannya dengan budaya 
bersalaman, karena mereka yang tidak bersalaman dengan yang bukan mukhrim mengetahui hukumnya dengan kajian-kajian keagamaan yang mereka dipelajari dan untuk menjaga wudhu di pagi hari saat mengaji dan berdoa sebelum pembelajaran di mulai.

\section{Kesimpulan}

Nilai-nilai pendidikan Islam yang tertanam di SMA Negeri 1 Genteng terbagi menjadi tiga nilai yaitu: Nilai Ubudiyah yang ditanamkan di SMA Negeri 1 Genteng dapat dilihat dari adanya kesadaran melaksanakan ibadah, dan kewajiban melaksanakan ibadah. Sementara nilai moralitas yang ditanamkan di SMA Negeri 1 Genteng dengan indikator kesantunan, kegotongroyongan, Kedermawanan. Sedangkan nilai kedisiplinan yang ada di SMA negeri 1 Genteng adalah adanya beberapa indikator yang menjadikan nilai kedisiplinan di sana sangat baik meliputi tanggung jawab, komitmen yang tinggi, serta etos kerja yang tinggi. Sementara proses penanaman nilai-nilai pendidikan Islam di SMA Negeri 1 Gentengdilaksanakan dalam bentuk keteladanan, Pembiasaan, dan nasihat. Faktor pendukung dan Faktor penghambat Penanaman Nilai-nilai Pendidikan Islam di SMA Negeri 1 Genteng adalah adanya dukungan lembaga pendidikan dan kekompakan dari warga sekolah dalam menanamkan nilai-nilai pendidikan Islam.Sedangkan faktor penghambat dari penanaman nilai-nilai pendidikan Islam terdapat pada penanaman nilai moralitas, ada beberapa hal yang menjadikan dalam penanamnya sedikit terkendala, seperti budaya bersalaman karena mereka yang tidak bersalaman dengan yang bukan mukhrim.Namun hal ini dapat diatasi dengan adanya penanaman sebuah pemahaman dan pengertian bersama sebagai solusinya. 


\section{Daftar Pustaka}

Ansori, Raden Ahmad Muhajir, 2017. Strategi Penanaman Nilai- nilai Pendidikan Islam Pada Peserta Didik. Jurnal Pusaka. Vol 4 No 2 Edisi 8. Malang. Diakses pada tanggal 11 Juni 2018. (http://ejournal.alqolam.ac.id/index.php/jurnal_pusaka/article/view/strategi -penanaman-nilai-islam)

Asmani, Jamal Ma'mur, 2013. Buku Panduan Internalisasi Pendidikan Karakter di Sekolah. Cetakan. VI. Yogyakarta: DIVA Press.

Kurnialoh, Nasri, 2012. Pendidikan Karakter dan Dinamika Kekerasan. Kependidikan Islam: Jurnal Pemikiran, Riset dan Pengembangan Pendidikan Islam. Vol. 7. No. 2. Yogyakarta: Jurusan Kependidikan Islam Fakultas Tarbiyah dan Keguruan UIN Sunan Kalijaga Yogyakarta.

Peraturan Pemerintah Republik Indonesia Nomor 55 Tahun 20017 Tentang Pendidikan Agama dan Pendidikan Keagamaan. Diakses pada tanggal 04 Agustus 2018. (https://kemenag.go.id/file/dokumen/PP5507.pdf).

Sahlan, Asmaun, 2010. Merwujudkan Budaya Religius di Sekolah (Upaya Mengembangkan PAI dari Teori ke Aksi). Malang: UIN-MALIKI PRESS.

Taufiqurrahman, 2018. Guru SMA di Sampang Meninggal Dianiaya Siswanya, Kini Pelaku Diamankan Polisi. Diakses pada tanggal 2 April 2018 (https://regional.kompas.com/read/2018/02/02/11344891/guru-smadi-sampang-meninggal-dianiaya-siswanya-kini-pelaku-diamankan-polisi).

Zamzami, M. Cholid, 2015. Penguatan Pengalaman Keagamaan di Sekolah .Jurnal PAI. Vol. 1 No. 2. Diambil pada tanggal 11 Juni 2018 (http://repository.uin-malang.ac.id/694/3/penguatan.pdf).

Zulkarnain, 2008. Transformasi Nilai-nilai Pendidikan Islam Manajemen Beorientasi Link and Match. Yogyakarta: Pustaka Pelajar. 